EXTENDED REPORT

\title{
Acquired resistance of human $T$ cells to sulfasalazine: stability of the resistant phenotype and sensitivity to non- related DMARDs
}

\author{
J van der Heijden, M C de Jong, B A C Dijkmans, W F Lems, R Oerlemans, I Kathmann, \\ G L Scheffer, R J Scheper, Y G Assaraf, G Jansen
}

Ann Rheum Dis 2004;63:131-137. doi: 10.1136/ard.2003.006494

See end of article for authors' affiliations

Correspondence to: Dr G Jansen, Department of Rheumatology $4 \mathrm{~A} 42$ Vrije Universiteit Medical Centre, De Boelelaan $1117,1081 \mathrm{HV}$ Amsterdam, The Netherlands; g.jansen@vumc.nl

Accepted 21 July 2003

\begin{abstract}
Background: A recent study from our laboratory showed that induction of the multidrug resistance related drug efflux pump $A B C G 2$ contributed to acquired resistance of human $T$ cells to the disease modifying antirheumatic drug (DMARD) sulfasalazine (SSZ).

Objectives: To investigate the duration of SSZ resistance and ABCG2 expression after withdrawal of SSZ and rechallenging with SSZ, and to assess the impact of SSZ resistance on responsiveness to other DMARDs.

Methods: Human CEM cells (T cell origin) with acquired resistance to SSZ (CEM/SSZ) were characterised for (a) SSZ sensitivity and ABCG2 expression during withdrawal and rechallenge of SSZ, and (b) antiproliferative efficacy of other DMARDs.

Results: ABCG2 protein expression was stable for at least 4 weeks when CEM/SSZ cells were grown in the absence of SSZ, but gradually declined, along with SSZ resistance levels, to non-detectable levels after withdrawal of SSZ for 6 months. Rechallenging with SSZ led to a rapid ( $<2.5$ weeks) resumption of SSZ resistance and $A B C G 2$ expression as in the original CEM/SSZ cells. CEM/SSZ cells displayed diminished sensitivity to the DMARDs leflunomide $(5.1$-fold) and methotrexate $(1.8$-fold), were moderately more sensitive (1.6-2.0 fold) to cyclosporin $A$ and chloroquine, and markedly more sensitive (13-fold) to the glucocorticoid dexamethasone as compared with parental CEM cells.

Conclusion: The drug efflux pump ABCG2 has a major role in conferring resistance to SSZ. The collateral sensitivity of SSZ resistant cells for some other (non-related) DMARDs may provide a further rationale for sequential mono- or combination therapies with distinct DMARDs upon decreased efficacy of SSZ.
\end{abstract}

A cquired drug resistance is recognised as a common cause of treatment failure for patients with cancer after sustained treatment with cytostatic drugs. ${ }^{12}$ An important mechanism of acquired cellular drug resistance to anticancer drugs is the overexpression of drug efflux pumps belonging to the superfamily of adenosine triphosphate dependent binding cassette $(\mathrm{ABC})$ transporters..$^{2-6} \mathrm{ABC}$ transporters with an established role in drug efflux and drug resistance include (a) P-glycoprotein (Pgp, ABCBl), which confers resistance preferentially to lipophilic drugs $;(b)$ members of the multidrug resistance associated protein subfamily (MRP1-6, ABCC1-6), which confer resistance to various anionic charged/glutathione conjugated drugs such as methotrexate (MTX), ${ }^{8}$ thiopurines, ${ }^{9}{ }^{10}$ and steroids ${ }^{5}{ }^{11}$; and (c) ABCG2, also known as breast cancer resistance protein (BCRP), a recently identified $\mathrm{ABC}$ transporter that confers resistance to amphiphilic drugs, including mitoxantrone and MTX. $^{12}{ }^{13}$

In clinical rheumatology, loss of drug efficacy is also noted for patients with rheumatoid arthritis (RA) receiving long term treatment with disease modifying antirheumatic drugs (DMARDs). ${ }^{14-17}$ Whether this loss of DMARD efficacy is related to the onset of acquired resistance to DMARDs, with mechanisms similar to anticancer drug resistance, is not known. ${ }^{18}$ Meta-analyses of DMARD treatment termination rates showed that the DMARD sulfasalazine $(\mathrm{SSZ})^{19} 20$ had a relatively shorter lasting efficacy than other DMARDs, in particular the "gold standard" MTX. ${ }^{14}{ }^{16-18}$ In general, lack of efficacy may be related to diminished antiinflammatory and/or antiproliferative effects of DMARDs against proinflammatory cytokine releasing cells at inflammatory sites. ${ }^{21}$

To gain insight into the possible mechanism(s) of resistance to the antiproliferative/anti-inflammatory effects of the DMARD SSZ, we previously provoked acquired resistance to SSZ in an in vitro model system of human $\mathrm{T}$ lymphocytes by stepwise exposure of CEM (T) cells to gradually increasing concentrations of SSZ. ${ }^{22}$ This study showed that SSZ resistance in CEM (T) cells was conferred by overexpression of a drug efflux pump-notably, the multidrug resistance transporter ABCG2/BCRP. Owing to enhanced drug efflux in SSZ resistant cells (CEM/SSZ), higher concentrations of SSZ were required to inhibit the secretion of the proinflammatory cytokine tumour necrosis factor $\alpha(\mathrm{TNF} \alpha){ }^{22}$

In the present study we investigated the stability of the resistant phenotype of CEM/SSZ cells after withdrawal of SSZ in order to establish whether SSZ resistance is slowly/rapidly lost over time and reinducible after SSZ rechallenge. Moreover, we analysed to what extent SSZ resistance affected antiproliferative effects of other DMARDs and anti-inflammatory drugs. The results demonstrated that SSZ resistance,

\footnotetext{
Abbreviations: $A B C$, ATP binding cassette; $B C R P$, breast cancer resistance protein; DMARDs, disease modifying antirheumatic drugs; $\mathrm{FCS}$, fetal calf serum; $\mathrm{IC}_{50}$, drug concentration required to inhibit cell growth by $50 \%$; $M D R$, multidrug resistance; $M R P 1$, multidrug resistance associated protein 1; MTX, methotrexate; $N F \kappa B$, nuclear factor $\kappa B ; P g p$, P-glycoprotein; SSZ, sulfasalazine; TNF $\alpha$, tumour necrosis factor $\alpha$
} 
along with ABCG2 expression, was gradually lost over a period of 6 months after withdrawal of SSZ, but rapidly reemerged, within 2 weeks, upon rechallenge with SSZ. Drug sensitivity was as follows: CEM/SSZ cells displayed lower sensitivity (fivefold) to the DMARD leflunomide, a slightly diminished sensitivity to MTX (twofold), moderately increased sensitivities for cyclosporin $\mathrm{A}$ and chloroquine (up to twofold), but a markedly enhanced sensitivity for dexamethasone (13-fold).

\section{MATERIALS AND METHODS Materials}

Sulfasalazine, leflunomide, chloroquine, phenylmethylsulfonyl fluoride (PMSF), and dexamethasone were purchased from Sigma Chemical Co (St Louis, MO, USA). Protease inhibitor cocktail and Triton X-100 were from Boehringer Mannheim (Ingelheim, Germany). MG132 was from Calbiochem (Germany). MTX was a generous gift from Pharmachemie Haarlem, the Netherlands. Cyclosporin A was a gift from Novartis (Arnhem, the Netherlands). The ABCG2 inhibitor Ko $143^{23}$ was kindly provided by Dr A Schinkel (Netherlands Cancer Institute, Amsterdam, the Netherlands). RPMI-1640 tissue culture medium and fetal calf serum (FCS) were obtained from Gibco Chemical Co, Grand Island NY, USA.

Cell culture and selection of SSZ resistant CEM (T) cells SSZ resistant human CEM (T) cells were isolated as described previously. ${ }^{22}$ In short, human CEM (T) cells were cultured at an initial density of $3 \times 10^{5}$ cells/ml in RPMI- 1640 medium supplemented with $10 \%$ FCS, $2 \mathrm{mM}$ L-glutamine, and $100 \mu \mathrm{g} / \mathrm{ml}$ penicillin and streptomycin in a $5 \% \mathrm{CO}_{2}$ incubator at $37^{\circ} \mathrm{C} .{ }^{24}{ }^{25} \mathrm{Cell}$ cultures were refreshed twice weekly and SSZ was added to the cell culture medium at an initial concentration of $0.4 \mathrm{mmol} / \mathrm{l}$. This concentration of SSZ could be stepwise increased to $1.5 \mathrm{mM} \mathrm{SSZ}$ (after 4 months) and $2.5 \mathrm{mM}$ SSZ after a period of 6 months.

Extensive binding of SSZ to plasma proteins (serum albumin) is known to limit its therapeutic effect. ${ }^{26}{ }^{27}$ Based on the presence of at least three classes of SSZ binding sites on serum albumin and their association rate constants ${ }^{28}$ it can be calculated that a protein concentration of about $100 \mu \mathrm{mol} / \mathrm{l}$ in $10 \%$ FCS can bind $320 \mu \mathrm{M} \mathrm{SSZ}$. For the two selected SSZ resistant CEM cells grown in the presence of 1.5 and $2.5 \mathrm{mM} \mathrm{SSZ}$, this would imply that $21 \%$ and $13 \%$ of SSZ, respectively, is protein bound.

It should be recognised that CEM cells are of $\mathrm{T}$ cell leukaemic origin, proliferating with a doubling time of 2630 hours. Thus CEM cells may not fully representative for normal $\mathrm{T}$ cells or $\mathrm{T}$ cells applicable to RA. However, CEM cells may serve as a valuable in vitro model system for RA research as they respond to $\mathrm{T}$ cell stimuli, producing proinflammatory cytokines like TNF $\alpha{ }^{22}$ Furthermore, CEM cells have been exploited to disclose resistance mechanisms to MTX that are clinically encountered..$^{24}$ 29-31

Antiproliferative effects of DMARDs and other drugs were analysed by plating $1.25 \times 10^{5}$ cells/ml of parental CEM (T) cells, CEM/SSZ1.5, and CEM/SSZ2.5 cells (in the absence of SSZ) in individual wells of a 24 well plate containing up to $50 \mu \mathrm{l}$ of drug solution. Inhibition of cell growth was determined after 72 hours' incubation by counting cells with a haemocytometer and cell viability by trypan blue exclusion. The drug concentration required to inhibit cell growth by $50 \%$ compared with control growth is defined as the $\mathrm{IC}_{50}$ concentration.

\section{Western blotting}

For analysis of expression of ABCG2/BCRPand ABCC1/MRP1, cells were harvested in the mid-log phase of growth and washed three times with ice cold Hepes buffered saline, $\mathrm{pH}$ 7.4. Total cell lysates of $10^{7}$ cells were suspended in $500 \mu \mathrm{l}$ of lysis buffer containing $50 \mathrm{mM}$ Tris- $\mathrm{HCl}$ (pH 7.6), $5 \mathrm{mM}$ dithiothreitol, $20 \mu \mathrm{l}$ protease inhibitor cocktail (one tablet $/ \mathrm{ml}$ $\left.\mathrm{H}_{2} \mathrm{O}\right), 20 \%$ glycerol, and $0.5 \% \mathrm{NP}-40$. The suspension was sonicated (MSE sonicator, amplitude 6 , for $3 \times 5$ seconds with 30 seconds time intervals at $4^{\circ} \mathrm{C}$ ) and centrifuged in an Eppendorf microcentrifuge (10 minutes, $14000 \mathrm{rpm}, 4^{\circ} \mathrm{C}$ ). Protein content of the supernatant was determined by Biorad protein assay. ${ }^{32}$ Fifty microgram of total cell lysates was fractionated on a $7.5 \%$ polyacrylamide gel and transferred onto a nitrocellulose membrane. The nitrocellulose membranes were preincubated overnight at $4^{\circ} \mathrm{C}$ in blocking buffer (5\% Biorad Blocker in TBS-T ( $10 \mathrm{mM}$ Tris-HCl, pH 8.0, $0.15 \mathrm{M} \mathrm{NaCl}, 0.1 \%$ Tween-20) to prevent aspecific antibody binding. After blocking, the membranes were incubated for 1 hour at room temperature with the primary antibodies for the multidrug resistant (MDR) pumps ABCG2/BCRP (BXP21, 1:400) and MRPl (MRPrl, 1:500) as described by Scheffer et al. ${ }^{32} 33$ As control for protein loading, $\beta$-actin (Chemicon International, Ca, USA: 1:3000) was used. After three washing steps with TBS-T, membranes were incubated for 1 hour with horseradish peroxidase labelled antirat/mouse (Dako; 1:2000 for ABCG2/BCRP and ABCCl/MRP1, and $1: 3000$ for $\beta$-actin) as secondary antibody. Detection of the antibody binding was measured by enhanced chemiluminescence according to the manufacturer's instructions (Amersham International, Buckinghamshire, UK). Protein levels were determined by densitometric scanning (GelDoc and Molecular Analyst, Biorad Laboratories) of the $x$ ray films (Hyperfim ECL, Amersham International, Buckinghamshire, UK).

\section{Statistical analysis}

Statistical significance of differences was analysed by analysis of variance using SPSS 9.0 computer software. A p value $<0.05$ was considered to be significantly different.

\section{RESULTS}

Onset and stability of SSZ resistance in human CEM (T) cells

Acquired resistance to SSZ in human CEM (T) cells could be provoked by culturing cells in stepwise increasing concentrations of SSZ. ${ }^{22}$ Figure 1A (point A) shows the antiproliferative effect of SSZ ( $\mathrm{IC}_{50}$ : concentration for $50 \%$ growth inhibition) for CEM (T) cells at the initial dosing of $0.4 \mathrm{mM} \mathrm{SSZ}$, and for CEM $(\mathrm{T})$ cells that were grown in the presence of stepwise increasing concentrations of SSZ. After a period of 4 months, CEM (T) could be maintained at an $\mathrm{IC}_{50}$ concentration of $1.5 \mathrm{mM}$ SSZ (CEM/SSZ1.5) which was about fourfold higher than parental CEM (T) cells. When CEM/SSZ1.5 cells were grown in the presence of $1.5 \mathrm{mM} \mathrm{SSZ}$ for another 2 months, the $\mathrm{IC}_{50}$ value slightly increased to $1.7 \mathrm{mM}$ (fig $1 \mathrm{~A}$, point $\mathrm{B}$ ). When, in parallel, CEM/SSZ1.5 cells obtained after 4 months were exposed to further increasing concentrations of SSZ for 2 months, eventually CEM/SSZ2.5 cells were obtained that could grow in the presence of $2.5 \mathrm{mM} \mathrm{SSZ}$ (not shown).

To establish whether the SSZ resistance in CEM/SSZ1.5 cells is a transient or stable phenotype, CEM/SSZ1.5 cells (at point B) were further grown in the absence of SSZ, and $\mathrm{IC}_{50}$ values for the CEM/SSZ1.5 cells were monitored over time. After 1 week in the absence of SSZ, IC 50 values for SSZ dropped by $40-50 \%$ to stay at this level for up to 4 weeks. From this point on, $\mathrm{IC}_{50}$ values for SSZ gradually declined to reach ultimately the original levels of SSZ sensitivity of parental CEM (T) cells (point $\mathrm{C}$ ). To assess whether SSZ resistance would be reinduced upon exposure to SSZ, revertant CEM/SSZ1.5 cells were re-exposed to $1.5 \mathrm{mM}$ SSZ. Within only 2.5 weeks' exposure to SSZ (D), revertant 
A

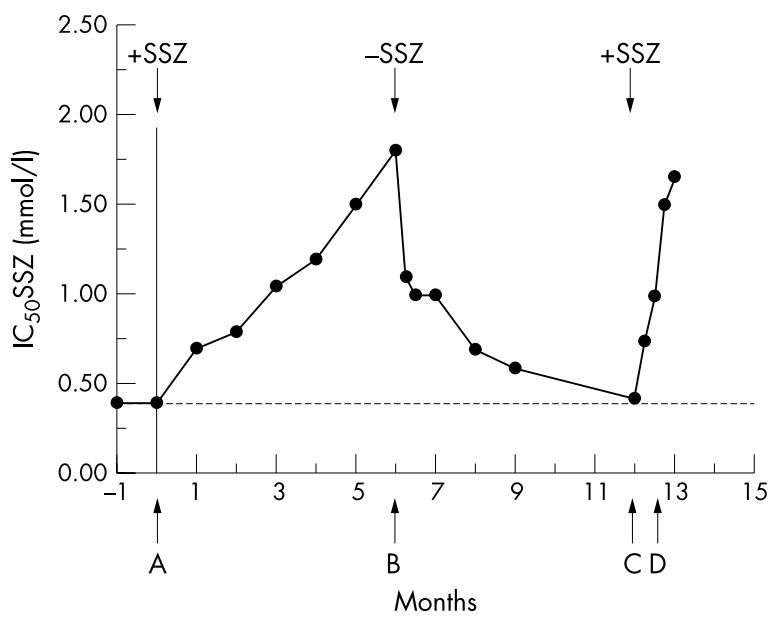

B

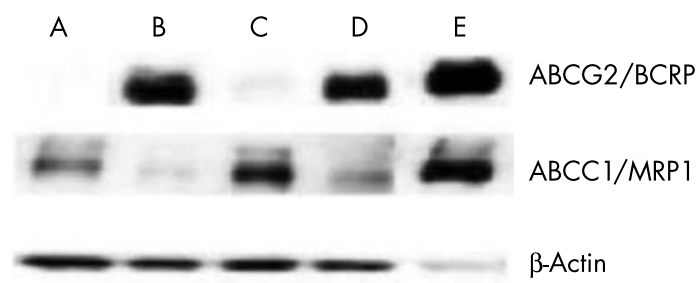

Figure 1 (A) Time course of sensitivity to sulfasalazine (SSZ) of CEM (T) during development of SSZ resistance, after withdrawal of SSZ from CEM/SSZ1.5 cells and rechallenge of revertant CEM/SSZ1.5 cells with SSZ. Parental CEM (T) cells (point A) were exposed to a starting concentration of $0.4 \mathrm{mM}$ SSZ that was gradually increased to $1.5 \mathrm{mM}$ over a period of 6 months to yield SSZ resistant CEM/SSZ1.5 cells (point B). From this point on CEM/SSZ1.5 were grown in the absence of SSZ to finally yield revertant CEM/SSZ1.5 cells that displayed again parental CEM (T) cell sensitivity to SSZ (point C). When revertant cells were reexposed to $1.5 \mathrm{mM}$ SSZ for 2.5 weeks (point D), CEM/SSZ1.5 resumed their original resistance level as observed at point $B$. $I C_{50}$ values were determined after 72 hours' exposure of cells to SSZ. (B) ABCG2/BCRP and $A B C C l / M R P 1$ protein expression, and mitoxantrone sensitivity of CEM (T) cells and (revertant) CEM/SSZ1.5 cells isolated at the various time points A-D. Cell lysates of $2008 / M_{R P 1}{ }^{32}$ and MCF7/MR ${ }^{43}$ served as positive controls for $A B C C 1 / M R P 1$ and $A B C G 2 / B C R P$, respectively (not shown). For CEM (T) and CEM/SSZ1.5 cells, $50 \mu \mathrm{g}$ of total cell lysate was applied on the sodium dodecyl sulphate polyacrylamide gel, and for the controls $10 \mu \mathrm{g}$ protein. $A B C C 1 / M R P 1$ was detected by the monoclonal antibody MRPr1, and ABCG2/BCRP was detected by the monoclonal antibody BXP21. ${ }^{32} \beta$-Actin was used as a control for equal protein loading.

CEM/SSZ1.5 cells resumed their original level of SSZ resistance as seen at point $\mathrm{B}$. These results indicate that although SSZ resistance in CEM/SSZ is transiently lost over a period of 6 months, rechallenge of revertant cells with SSZ rapidly reinduces resistance to SSZ.

\section{Expression of MDR transporters ABCG2/BCRP and $A B C C 1 / M R P 1$ in CEM (T) and CEM/SSZ cells}

Initial studies from our laboratory ${ }^{22}$ reported differential expression of MDR proteins upon development of SSZ resistance in CEM/SSZ cells: induction of ABCG2/BCRP and down regulation of $\mathrm{ABCC} / \mathrm{MRPl}$ expression. Figure $1 \mathrm{~B}$ illustrates the expression of ABCG2/BCRP and ABCCl/ MRPl at the various times A-D in fig 1A. Parental CEM (T) cells (point A, fig lA) exhibited undetectable levels of expression of ABCG2/BCRP protein, but had an appreciable level of $\mathrm{ABCC} / \mathrm{MRP1}$. In contrast, SSZ resistant CEM cells isolated at $1.5 \mathrm{mM} \mathrm{SSZ} \mathrm{(CEM/SSZ1.5} \mathrm{cells)} \mathrm{(fig} \mathrm{1A,} \mathrm{point} \mathrm{B)}$ showed a marked induction of ABCG2/BCRP expression and down regulation of ABCCl/MRPl expression. After withdrawal of SSZ from the cell culture of CEM/SSZ1.5 for a period of 6 months (fig lA, point C) ABCG2/BCRP and $\mathrm{ABCC}$ /MRPl expression reverted to the original levels of parental CEM (T) cells. Notably, when revertant CEM/SSZ1.5 were re-exposed to $1.5 \mathrm{mM}$ SSZ for 2.5 weeks (fig 1A, point D), ABCG2/BCRP expression was rapidly up regulated, while ABCCl/MRPl was again down regulated. As a control, fluctuations in the expression of ABCG2/BCRP paralleled the growth inhibitory effects $\left(\mathrm{IC}_{50}\right.$ values) for the cytostatic drug mitoxantrone, which is a known substrate for efflux by ABCG2/BCRP ${ }^{64}$ (data not shown).

Because fig $1 \mathrm{~A}$ showed that changes in $\mathrm{IC}_{50}$ values for CEM/SSZ1.5 cells were particularly noted within the first 10 weeks after withdrawal of SSZ (fig $1 \mathrm{~A}$, point $\mathrm{B} \rightarrow \mathrm{C}$ ), we fine tuned the analysis of $\mathrm{IC}_{50}$ values for SSZ and changes in expression of ABCG2/BCRP and ABCCl/MRPl during this period of 10 weeks. IC $_{50}$ values for SSZ dropped by about 40 $50 \%$ after growth of CEM/SSZ1.5 cells in the absence of SSZ for 1 week (fig $2 \mathrm{~A}$ ). From this point on, $\mathrm{IC}_{50}$ values for SSZ only slowly declined. At 70 days after withdrawal of SSZ from CEM/SSZ1.5 cells, resistance to SSZ could still be noted compared with parental CEM (T) cells. Figure 2B shows the expression of ABCG2/BCRP and ABCCl/MRPl in parental CEM (T) cells (lane A) compared with CEM/SSZ1.5 cells before (lane B) and after withdrawal of SSZ for 3 days, 7 days, 4 weeks, and 10 weeks (lanes C-F, respectively). ABCG2/BCRP protein expression in CEM/SSZ1.5 cells appeared to be stable for at least 4 weeks after withdrawal of SSZ, after which a diminished, but still detectable, level of expression could be seen after 10 weeks. ABCCl/MRPI expression, which was down regulated in CEM/SSZ1.5 cells in the presence of SSZ, was rapidly reinduced within 37 days after withdrawal of SSZ, even overshooting the level of ABCCl/MRPl expression in parental CEM (T) cells after 70 days of SSZ withdrawal from CEM/SSZ1.5 cells. These results indicate that $\mathrm{ABCG} / \mathrm{BCRP}$ and $\mathrm{ABCCl} / \mathrm{MRP} 1$ follow an inverse pattern of expression after SSZ exposure/withdrawal.

Given the apparent discrepancy of the rapid partial loss of SSZ resistance within 1 week of withdrawal of SSZ from CEM/SSZ1.5 cells (fig 2A) and the stable expression of ABCG2/BCRP during this period (fig 2B, lanes B-D), we further investigated the functional contribution of ABCG2/ BCRP in SSZ resistance by blocking ABCG2/BCRP with a specific inhibitor, Ko $143 .{ }^{23}$ Blocking of ABCG2/BCRP reversed SSZ resistance in CEM/SSZ1.5 cells by $50-60 \%$, but not completely, to parental CEM (T) cell sensitivity (fig 2C). After growth of CEM/SSZ1.5 cells in the absence of SSZ for 4 weeks, when $\mathrm{IC}_{50}$ values for SSZ had stabilised at about $50 \%$ of the original CEM/SSZ1.5 cells, Kol43 fully reversed the residual SSZ resistance of CEM/SSZ1.5 cells to the SSZ sensitivity of CEM (T) cells (fig 2C). These results indicate that SSZ resistance in CEM/SSZ1.5 is mediated by at least two components, each contributing about $50 \%$. One component, is rapidly lost within one week after withdrawal of SSZ, the other component, which stabilised after 1-4 weeks' growth of CEM/SSZ1.5 cells in the absence of SSZ, can be fully accounted for by ABCG2/BCRP. The latter component is then gradually lost over period of 5 months' culture in the absence of SSZ.

\section{Sensitivity profile of CEM/SSZ cells for DMARDs and other anti-inflammatory drugs}

In clinical rheumatology, SSZ is applied sequentially in mono- and/or combination therapies with other DMARDs. ${ }^{19320}$ For this reason, we investigated whether the onset of SSZ resistance affects the sensitivity for other clinically active DMARDS, as well as other drugs with 


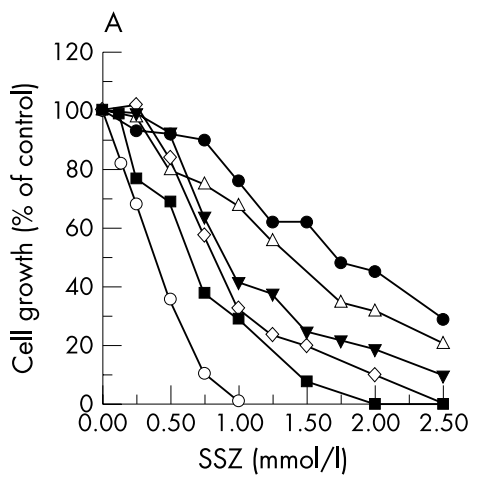

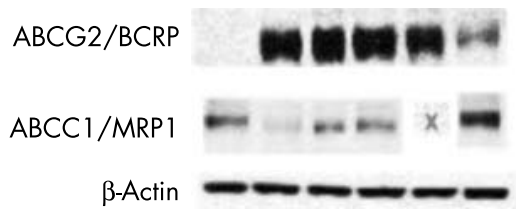

A $\quad B \quad C \quad D \quad E \quad F$

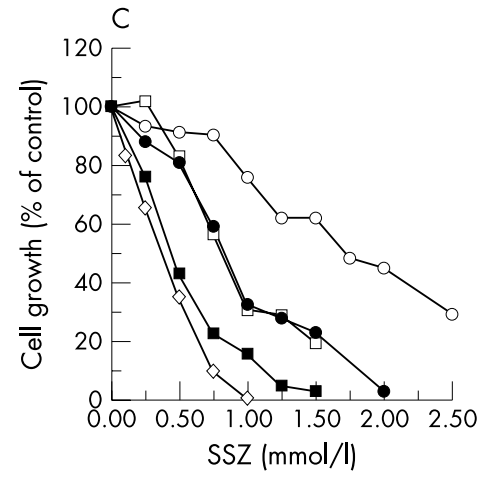

Figure 2 (A) Antiproliferative effect of SSZ against CEM/SSZ1.5 cells isolated at various times (0-10 weeks) after withdrawal of SSZ from CEM/ SSZ1.5 cells from point B in fig 1A: 0 days (closed circles), 3 days (open triangles), 1 week (closed triangles), 4 weeks (open diamonds), 10 weeks (closed squares). Antiproliferative effects/growth inhibition for SSZ were evaluated after 72 hours' exposure to SSZ and compared with those for parental CEM (T) cells (open circles). (B) Expression of ABCG2/BCRP and ABCC1/MRP1 protein of CEM/SSZ1.5 cells during withdrawal of SSZ for up to 10 weeks as in fig 2A. Lane A: parental CEM (T) cells; lane B: CEM/SSZ1.5 cells before withdrawal of SSZ; lanes C-F: CEM/SSZ1.5 cells 3 days, 7 days, 4 weeks, and 10 weeks, respectively, after withdrawal of SSZ. Note: sample E for ABCC1/MRP1 was not tested. (C) Reversal of SSZ resistance in CEM/SSZ1.5 cells by the ABCG2/BCRP blocker Kol 43 before and after 4 weeks' withdrawal of SSZ. Symbols: (open triangle) parental CEM (T) cells, (open circles) CEM/SSZ1.5 cells, (closed circles) CEM/SSZ cells $+0.5 \mu \mathrm{M}$ Kol 43 , (open squares) CEM/SSZ1.5 cells after 4 weeks' withdrawal of SSZ, (closed squares) CEM/SSZ1.5 cells after 4 weeks withdrawal of SSZ $+0.5 \mu \mathrm{M}$ SSZ. Antiproliferative effects of SSZ were evaluated after 72 hours' exposure to SSZ in the absence or presence of Kol 43.

potentially anti-inflammatory properties. Drug sensitivities were evaluated by their antiproliferative effects for CEM/ SSZ1.5 and CEM/SSZ2.5 cells as compared with parental CEM ( $\mathrm{T}$ ) cells (table 1 ).

Cross resistance to mitoxantrone, a topoisomerase II inhibitor that is a prototypical substrate for ABCG2/ $\mathrm{BCRP}^{34}{ }^{36}$ for both CEM/SSZ1.5 (4.3-fold, $\mathrm{p}=0.002 v$ CEM ) and CEM/SSZ2.5 cells $(6.4$-fold, $\mathrm{p}<0.001 \quad v$ CEM), was studied. As expected, mitoxantrone cross resistance was fully reversed by the ABCG2/BCRP blocker Kol43. Furthermore, cross resistance of CEM/SSZ cells was noted for the DMARDs leflunomide (up to 5.1-fold for CEM/SSZ2.5, $\mathrm{p}=0.005 \mathrm{v}$ CEM) and MTX (up to 1.8-fold for CEM/SSZ2.5, $\mathrm{p}=0.027 \mathrm{v}$ CEM). Because SSZ mediates part of its anti-inflammatory effects by targeting the NFKB signalling pathway, ${ }^{37}{ }^{38}$ we also determined the drug sensitivity for MG132, an inhibitor of NFKB activation through inhibition of 26S-proteasome. ${ }^{39} \mathrm{~A}$ low level of cross resistance for CEM/SSZ cells was noted for MG132 ( 1.6 -fold, $\mathrm{p}=0.004$ for CEM/SSZ2.5 and $\mathrm{p}<0.001$ for CEM/SSZ1.5 $v$ CEM). Interestingly, enhanced sensitivity of CEM/SSZ cells was noted for the DMARDs chloroquine (up to 1.9-fold CEM/SSZ2.5, $\mathrm{p}=0.043 v \mathrm{CEM}$ ) and cyclosporin A (up to 1.6-fold, $\mathrm{p} \leqslant 0.001$ for CEM/SSZ1.5 and $\mathrm{p}=0.028$ for CEM/SSZ2.5 $v$ CEM). CEM/SSZ cells displayed even more hypersensitivity (up to 13-fold, $\mathrm{p}=0.002$ for CEM/SSZ1.5 and $\mathrm{p}=0.003$ for CEM/SSZ2.5 $v$ CEM) to the glucocorticoid dexamethasone. These results indicate that induction of SSZ resistance can coincide with a differentially altered DMARD sensitivity pattern, including, on the one hand, cross resistance to leflunomide and MTX, but on the other, enhanced sensitivity to cyclosporin A and chloroquine, and, most notably, to dexamethasone.

\section{DISCUSSION}

Characterisation of human CEM (T) cells with acquired resistance to the DMARD SSZ showed differential expression of two MDR efflux pumps: up regulation of ABCG2/BCRP and down regulation of ABCCl/MRPl. This phenotype could be reverted (slowly) and reinduced (rapidly) after SSZ withdrawal and SSZ re-exposure, respectively. Beyond this, CEM/SSZ cells were characterised by enhanced sensitivity to the DMARDs cyclosporin A and chloroquine, and most notably to dexamethasone, which may provide possible strategies to circumvent resistance to SSZ.

SSZ is commonly used in various DMARD regimens for RA treatment, including monotherapy or combination therapy with other DMARDs such as MTX, hydroxychloroquine or in the COBRA regimen. ${ }^{19} 203540$ SSZ can induce antiproliferative/

Table 1 Antiproliferative effects of DMARDs and other drugs against CEM (T) and CEM/ SSZ cells

\begin{tabular}{|c|c|c|c|}
\hline \multirow[b]{2}{*}{ DMARD/drug } & \multicolumn{3}{|l|}{$\mathrm{IC}_{50} \dagger[R F] \neq$} \\
\hline & CEM (T) & CEM/SSZ1.5 & CEM/SSZ2.5 \\
\hline $\operatorname{SSZ}(\mu \mathrm{M})$ & $400(30)[1]$ & $1720(170)[4.3]^{\star * *}$ & $2550(212)[6.4]^{\star \star *}$ \\
\hline Mitoxantrone $(\mathrm{nM})$ & $0.47(0.08)[1]$ & $1.94(0.67)[4.1]^{* *}$ & $3.3(0.6)[7.0]^{\star \star \star \star}$ \\
\hline Mitoxantrone (+Kol 143)§ & $0.33(0.07)[1]$ & $0.36(0.06)[1.1]$ & ND \\
\hline Leflunomide $(\mu M)$ & $17.2(1.9)[1]$ & $37.4\left(14.4\left[[2.2]^{\mathrm{NS}}\right.\right.$ & $88.0(37.4)[5.1]^{* *}$ \\
\hline Methotrexate $(\mathrm{nM})$ & $8.4(0.7)[1]$ & $9.0(0.7)[1.1]^{\mathrm{NS}}$ & $15.1(5.1)[1.8]^{*}$ \\
\hline MG132 (nM) & $39.5(5.0)[1]$ & $68.1(8.8)[1.7]^{* * *}$ & $63.1(7.9)[1.6]^{* *}$ \\
\hline Chloroquine ( $\mu \mathrm{M})$ & 44.5 (7.5) [1] & $37.8(8.7)[0.8]^{\mathrm{NS}}$ & $23.3(13.9)[0.5]^{*}$ \\
\hline Cyclosporin A $(\mu \mathrm{M})$ & $5.7(0.8)[1]$ & $3.6(0.8)[0.6]^{\star *}$ & $4.0(0.2)[0.7]^{*}$ \\
\hline Dexamethasone $(\mathrm{nM})$ & $41.5(13.1)[1]$ & $3.4(0.6)[0.08]^{\star *}$ & $6.4(0.8)[0.15]^{\star *}$ \\
\hline
\end{tabular}

Statistical significance (analysis of variance test): $\mathrm{IC}_{50}$ CEM/SSZ v IC 50 CEM (T): ${ }^{*} \mathrm{p}<0.05$; ${ }^{* *} \mathrm{p}<0.01$; ${ }_{* * *}<<0.001$; NS, not significant.

$+\mathrm{IC}_{50}$ values were determined after 72 hours of DMARD/drug exposure. Values are mean (SD) of 3-6 separate experiments; $\neq(\mathrm{RF})$, resistance factor: IC $\mathrm{C}_{50} \mathrm{CEM} / \mathrm{SSZ}: \mathrm{IC}_{50}$ CEM (T); §100 nM Kol 43.

ND, not determined. 
apoptotic effects ${ }^{41}$ as well as anti-inflammatory effects by inhibiting activation of $\mathrm{NF \kappa B},{ }^{37}$ which leads to the decreased production/secretion of proinflammatory cytokines such as $\mathrm{TNF} \alpha{ }^{38}$ Although SSZ is a potent DMARD, its efficacy in long term treatment seems to be more compromised than that of other DMARDs, such as MTX. ${ }^{14}{ }^{16}{ }^{18}$ Because lack of efficacy may be related to either persistent/renewed disease activity and/or side effects of DMARDs, we suggested that diminished SSZ efficacy might also be associated with the development of resistance. Indeed, as previously reported, ${ }^{22}$ we found that the onset of SSZ resistance in human CEM (T) cells coincided with the induction of the MDR pump ABCG2/ BCRP. Thus far, ABCG2/BCRP induction had only been noted upon development of a selected group of topoisomerase inhibitors such as mitoxantrone, doxorubicin, and topotecan. ${ }^{12}{ }^{34} 42-44$

ABCG2/BCRP expression in CEM/SSZ cells did not fully account for the resistant phenotype as about $50 \%$ of the SSZ resistance was lost within one week after withdrawal of SSZ, whereas ABCG2/BCRP expression was unchanged. The nature of this latter component has not been identified, but may be related to SSZ-induced transient alterations in the $\mathrm{NF \kappa B}$ signalling pathway ${ }^{38}$ that controls the transcription of anti-apoptotic and proinflammatory cytokine/chemokine genes. ${ }^{45-47}$ Consistent with this hypothesis is the observation of a two- to threefold enhancement of TNF $\alpha$ production/ secretion by CEM/SSZ cells compared with CEM (T) cells. ${ }^{22}$ It remains to be established whether this type of SSZ resistance-induced effect may also be responsible for the altered antiproliferative effects (table 1) of NFкB signalling pathway drugs, including leflunomide, ${ }^{48} \mathrm{MG132}^{39}$ and dexamethasone..$^{45} 495$

The gradual loss of ABCG2/BCRP expression from cell cultures of CEM/SSZ1.5 cells after 6 months' (approximately 50 passages) withdrawal of SSZ is consistent with a study by Maliepaard et al, who noted the loss of ABCG2/BCRP expression from a topotecan resistant ovarian carcinoma cell line over 30 passages in drug-free medium. ${ }^{51}$ These results indicate that ABCG2/BCRP expression gradually declines when the selective pressure is absent, but can be rapidly resumed upon renewed exposure to the selective drug.

Besides the effects on ABCG2/BCRP expression, it is of interest to note that SSZ exposure/resistance had down regulatory effects on the expression of ABCCl/MRPl. Although this MDR transporter has an established role in extrusion of various toxic drugs, ${ }^{25}{ }^{11}$ it also has important immunological functions in, for instance, dendritic cells, where, by exporting the cysteinyl leucotriene LTC4, it mediates the signalling for chemokine CCL19 chemotaxis and migration of dendritic cells to the lymph nodes. ${ }^{52}$ Because SSZ is an inhibitor of LTC synthetase, ${ }^{53}$ impaired synthesis of LTC may parallel reduced expression of its transporter ABCCl/MRPl. Another example of ABCCl/MRPl down/up regulation was recently identified by our laboratory after depletion/repletion of cellular folate status ${ }^{54}$ in CEM (T) cells. Consistent with the notion that SSZ can also exert antifolate effects, ${ }^{55}$ we obtained preliminary evidence that the differential expression of ABCC1/MRP1 is indeed correlated with the cellular folate status in CEM/SSZ cells (Jansen G, Scheper RJ, Dijkmans BAC, unpublished data).

The present study also provides insight into strategies that may or may not be successful to circumvent/reverse SSZ resistance. Firstly, temporary discontinuation of DMARD treatment after an initial response and resumption of the treatment at the time of progressive disease proved to be effective. ${ }^{56}$ Whether a similar strategy is also effective for patients with RA for whom DMARD treatment has failed, has not been investigated. When such a clinical strategy was mimicked in vitro-discontinuation of SSZ treatment after development of SSZ resistance and rechallenging with SSZ at the time SSZ resistance had apparently disappeared-it did not seem to be effective. SSZ resistance, along with ABCG2/ BCRP overexpression, was rapidly reinduced $(<2.5$ weeks). Secondly, development of resistance to SSZ may be accompanied by adverse effects of collateral resistance to other DMARDs (for example, leflunomide) which might be used for sequential monotherapy. Potentially positive strategies to target SSZ resistance may include the use of $(a)$ blockers of ABCG2/BCRP that serve as chemosensitisers to reverse SSZ resistance (for example, Kol43); (b) DMARDs whose antiproliferative activity was not impaired during development of SSZ resistance, such as cyclosporin A and chloroquine. Because chloroquine is a substrate for efflux by $\mathrm{ABCC} 1 / \mathrm{MRP} 1$, a reduced expression of $\mathrm{ABCCl} / \mathrm{MRPl}$, as seen in CEM/SSZ cells, may confer enhanced sensitivity to chloroquine, ${ }^{57}$ which could increase the efficacy of hydroxychloroquine containing treatments. ${ }^{20}$ Finally, most interesting was the observation that CEM/SSZ cells displayed hypersensitivity (13-fold) to the glucocorticoid dexamethasone. One previous report has described collateral sensitivity to dexamethasone (10-fold) in human myeloma cells with acquired resistance to doxorubicin. ${ }^{58}$ The mechanistic basis for the markedly enhanced dexamethasone sensitivity is not clear, but is not associated with an increase in glucocorticoid receptor levels in CEM/SSZ cells compared with CEM (T) cells (not shown).

Altogether, this study shows that exposure/resistance to SSZ can have differential effects on the expression of at least two important MDR pumps: ABCG2/BCRP and ABCCl/ MRP1. As these MDR pumps are normally expressed on various peripheral blood cell types, ${ }^{59-61}$ further research is warranted to identify the expression levels of these MDR pumps during treatment of patients with RA with DMARDs which include SSZ. Thus far, only a few studies have investigated blood samples of patients with RA for differential expression of the MDR transporter Pgp. ${ }^{62-65}$ Although these studies included limited numbers of patients, data were supportive for a role of Pgp in DMARD efficacy. Our present study, though based on in vitro data using a $\mathrm{T}$ cell model system, demonstrates also that MDR pumps other than Pgp may be relevant for DMARD resistance. Once specific MDR proteins are identified for their contributing role in DMARD (in)efficacy, this information may be exploited to use specific blockers for the various MDR pumps ${ }^{2}$ as chemosensitisers for DMARD activity.

\section{ACKNOWLEDGEMENTS}

$\mathrm{J}$ van der Heijden is a recipient of the 2002 Arthron Young Investigator Fellowship.

This study is supported by a grant (NR03-1-402) from the Dutch Rheumatism Association (Nationaal Reumafonds).

\section{Authors' affiliations}

J van der Heijden, B A C Dijkmans, W F Lems, R Oerlemans, G Jansen, Department of Rheumatology, Vrije Universiteit Medical Centre, Amsterdam, The Netherlands

M C de Jong, R Oerlemans, G L Scheffer, R J Scheper, Department of Pathology, Vrije Universiteit Medical Centre, Amsterdam, The Netherlands

I Kathmann, Department of Medical Oncology, Vrije Universiteit Medical Centre, Amsterdam, The Netherlands

Y G Assaraf, Department of Biology, The Technion, Israel Institute of Technology, Haifa, Israel

\section{REFERENCES}

1 Bradshaw DM, Arceci RJ. Clinical relevance of transmembrane drug efflux as a mechanism of multidrug resistance. J Clin Oncol 1998;16:3674-90.

2 Borst P, Oude Elferink RP. Mammalian ABC transporters in health and disease. Annu Rev Biochem 2002;71:537-92. 
3 Borst P, Evers R, Kool M, Wijnholds J. A family of drug transporters: the multidrug resistance-associated proteins. J Natl Cancer Inst 2000;92: 1295-302

4 Gottesman MM, Ambudkar SV. Overview: $A B C$ transporters and human disease. J Bioenerg Biomembr 2001;33:453-8.

5 Leslie EM, Deeley RG, Cole SP. Toxicological relevance of the multidrug resistance protein 1, MRP1 (ABCC1) and related transporters. Toxicology $2001 ; 167: 3-23$.

6 Litman T, Druley TE, Stein WD, Bates SE. From MDR to MXR: new understanding of multidrug resistance systems, their properties and clinical significance. Cell Mol Life Sci 2001;58:931-59.

7 Gottesman MM, Fojo T, Bates SE. Multidrug resistance in cancer: role of ATPdependent transporters. Nat Rev Cancer 2002;2:48-58.

8 Hooijberg JH, Broxterman HJ, Kool M, Assaraf YG, Peters GJ, Noordhuis P, et al. Antifolate resistance mediated by the multidrug resistance proteins MRP1 and MRP2. Cancer Res 1999;59:2532-5.

9 Wiinholds J, Mol CA, van Deemter L, de Haas M, Scheffer GL, Baas F, et al. Multidrug-resistance protein 5 is a multispecific organic anion transporter able to transport nucleotide analogs. Proc Natl Acad Sci USA 2000;97:7476-81.

10 Wielinga PR, Reid G, Challa EE, van der Heijden I, van Deemter L, de Haas M, et al. Thiopurine metabolism and identification of the thiopurine metabolites transported by MRP4 and MRP5 overexpressed in human embryonic kidney cells. Mol Pharmacol 2002;62:1321-31

11 Renes J, de Vries EG, Jansen PL, Muller M. The (patho)physiological functions of the MRP family. Drug Resist Updat 2000;3:289-302.

12 Doyle LA, Yang W, Abruzzo LV, Krogmann T, Gao Y, Rishi AK, et al. A multidrug resistance transporter from human MCF-7 breast cancer cells. Proc Natl Acad Sci USA 1998;95:15665-70.

13 Volk EL, Farley KM, Wu Y, Li F, Robey RW, Schneider E. Overexpression of wild-type breast cancer resistance protein mediates methotrexate resistance. Cancer Res 2002;62:5035-40.

14 Wolfe $\mathbf{F}$. The epidemiology of drug treatment failure in rheumatoid arthritis Baillieres Clin Rheumatol 1995;9:619-32.

15 Wolfe F. Adverse drug reactions of DMARDs and DC-ARTs in rheumatoid arthritis. Clin Exp Rheumatol 1997;15(suppl 17):S75-81.

16 Maetzel A, Wong A, Strand V, Tugwell P, Wells G, Bombardier C. Metaanalysis of treatment termination rates among rheumatoid arthritis patients receiving disease-modifying anti-rheumatic drugs. Rheumatology (Oxford) 2000;39:975-81.

17 Aletaha D, Smolen JS. Effectiveness profiles and dose dependent retention of traditional disease modifying antirheumatic drugs for rheumatoid arthritis. An observational study. J Rheumatol 2002;29:1631-8.

18 Morgan C, Lunt M, Brightwell H, Bradburn P, Fallow W, Lay $M$, et al. Contribution of patient related differences to multidrug resistance in rheumatoid arthritis. Ann Rheum Dis 2003;62:15-19

19 Landewe RB, Boers M, Verhoeven AC, Westhovens $R$, van de Laar MA, Markusse $\mathrm{HM}$, et al. COBRA combination therapy in patients with early rheumatoid arthritis: long-term structural benefits of a brief intervention. Arthritis Rheum 2002;46:347-56

20 O'Dell JR, Leff R, Paulsen G, Haire C, Mallek J, Eckhoff PJ, et al. Treatment of rheumatoid arthritis with methotrexate and hydroxychloroquine, methotrexate and sulfasalazine, or a combination of the three medications: results of a twoyear, randomized, double-blind, placebo-controlled trial. Arthritis Rheum 2002;46:1164-70.

21 Cutolo M, Sulli A, Pizzorni C, Seriolo B, Straub RH. Anti-inflammatory mechanisms of methotrexate in rheumatoid arthritis. Ann Rheum Dis $2001 ; 60: 729-35$

22 van der Heijden J, de Jong MC, Dijkmans BAC, Lems WF, Oerlemans R, Kathmann GA, et al. Development of sulfasalazine resistance in human $T$ cells induces expression of the multidrug resistance transporter ABCG2 (BCRP) and augmented production of TNF $\alpha$. Ann Rheum Dis 2004;63:138-43

23 Allen JD, van Loevezijn A, Lakhai JM, van der Valk M, van Tellingen O, Reid $G$, et al. Potent and specific inhibition of the breast cancer resistance protein multidrug transporter in vitro and in mouse intestine by a novel analogue of fumitremorgin C. Mol Cancer Ther 2002;1:417-25.

24 Jansen G, Mauritz R, Drori S, Sprecher H, Kathmann I, Bunni M, et al. A structurally altered human reduced folate carrier with increased folic acid transport mediates a novel mechanism of antifolate resistance. J Biol Chem 1998;273:30189-98.

25 Mauritz R, Bekkenk MW, Rots MG, Pieters R, Mini E, Van Zantwijk CH, et al. Ex vivo activity of methotrexate versus novel antifolate inhibitors of dihydrofolate reductase and thymidylate synthase against childhood leukemia cells. Clin Cancer Res 1998;4:2399-410.

26 Das KM, Dubin R. Clinical pharmacokinetics of sulphasalazine. Clin Pharmacokinet 1976;1:406-25.

27 Azadkhan AK, Truelove SC, Aronson JK. The disposition and metabolism of sulphasalazine (salicylazosulphapyridine) in man. Br J Clin Pharmacol 1982;13:523-8.

28 Jansen JA. Kinetics of the binding of salicylazosulfapyridine to human serum albumin. Acta Pharmacol Toxicol (Copenh) 1977:41:401-16.

29 Mini E, Moroson BA, Franco CT, Bertino JR. Cytotoxic effects of folate antagonists against methotrexate-resistant human leukemic lymphoblast CCRF-CEM cell lines. Cancer Res 1985;45:325-30.

30 Mauritz R, Peters GJ, Priest DG, Assaraf YG, Drori S, Kathmann I, et al. Multiple mechanisms of resistance to methotrexate and novel antifolates in human CCRF-CEM leukemia cells and their implications for folate homeostasis. Biochem Pharmacol 2002;63:105-15.

31 Rots MG, Pieters R, Kaspers GJ, Veerman AJ, Peters GJ, Jansen G. Classification of ex vivo methotrexate resistance in acute lymphoblastic and myeloid leukaemia. Br J Haematol 2000;110:791-800.
32 Scheffer GL, Kool M, Heiin M, de Haas M, Piinenborg AC, Wiinholds J, et al. Specific detection of multidrug resistance proteins MRP1, MRP2, MRP3, MRP5, and MDR3 P-glycoprotein with a panel of monoclonal antibodies. Cancer Res 2000;60:5269-77.

33 Maliepaard M, Scheffer GL, Faneyte IF, van Gastelen MA, Pijnenborg AC Schinkel AH, et al. Subcellular localization and distribution of the breast cancer resistance protein transporter in normal human tissues. Cancer Res $2001 ; 61: 3458-64$.

34 Ross DD, Yang W, Abruzzo LV, Dalton WS, Schneider E, Lage H, et al. Atypical multidrug resistance: breast cancer resistance protein messenger RNA expression in mitoxantrone-selected cell lines. J Natl Cancer Inst 1999;91:429-33.

35 Goekoop YP, Allaart CF, Breedveld FC, Dijkmans BA. Combination therapy in rheumatoid arthritis. Curr Opin Rheumatol 2001;13:177-83.

36 Litman T, Brangi M, Hudson E, Fetsch P, Abati A, Ross DD, et al. The multidrug-resistant phenotype associated with overexpression of the new $A B C$ half-transporter, MXR (ABCG2). J Cell Sci 2000;113:2011-21.

37 Wahl C, Liptay S, Adler G, Schmid RM. Sulfasalazine: a potent and specific inhibitor of nuclear factor kappa B. J Clin Invest 1998;101:1163-74.

38 Tak PP, Firestein GS. NF-kappaB: a key role in inflammatory diseases. J Clin Invest 2001;107:7-11.

39 Lee DH, Goldberg AL. Proteasome inhibitors: valuable new tools for cell biologists. Trends Cell Biol 1998;8:397-403.

40 Barrera P, Haagsma CJ, Boerbooms AM, van Riel PL, Borm GF, van de Putte $L B$, et al. Effect of methotrexate alone or in combination with sulphasalazine on the production and circulating concentrations of cytokines and their antagonists. Longitudinal evaluation in patients with rheumatoid arthritis. Br J Rheumatol 1995;34:747-55.

41 Rodenburg RJ, Ganga A, van Lent PL, van de Putte LB, van Venrooij WJ. The antiinflammatory drug sulfasalazine inhibits tumor necrosis factor alpha expression in macrophages by inducing apoptosis. Arthritis Rheum 2000:43:1941-50

42 Bates SE, Robey R, Miyake K, Rao K, Ross DD, Litman T. The role of halftransporters in multidrug resistance. J Bioenerg Biomembr 2001;33:503-1 1 .

43 Taylor CW, Dalton WS, Parrish PR, Gleason MC, Bellamy WT, Thompson FH, et al. Different mechanisms of decreased drug accumulation in doxorubicin and mitoxantrone resistant variants of the MCF7 human breast cancer cell line. Br J Cancer 1991;63:923-9.

44 Scheffer GL, Maliepaard M, Pijnenborg AC, van Gastelen MA, de Jong MC, Schroeijers $A B$, et al. Breast cancer resistance protein is localized at the plasma membrane in mitoxantrone and topotecan resistant cell lines. Cancer Res 2000;60:2589-93.

45 Yamamoto Y, Gaynor RB. Therapeutic potential of inhibition of the NFkappaB pathway in the treatment of inflammation and cancer. $J$ Clin Invest 2001;107:135-42.

46 Baldwin AS. Control of oncogenesis and cancer therapy resistance by the transcription factor NF-kappaB. J Clin Invest 2001;107:241-6.

47 Chen F, Castranova V, Shi X. New insights into the role of nuclear factorkappaB in cell growth regulation. Am J Pathol 2001;159:387-97.

48 Manna SK, Mukhopadhyay A, Aggarwal BB. Leflunomide suppresses TNFinduced cellular responses: effects on NF-kappa B, activator protein-1, c-Jun $\mathrm{N}$-terminal protein kinase, and apoptosis. J Immunol 2000;165:5962-9.

49 Almawi WY, Melemedjian OK. Negative regulation of nuclear factor-kappaB activation and function by glucocorticoids. J Mol Endocrinol 2002;28:69-78.

50 Almawi WY, Abou Jaoude MM, Li XC. Transcriptional and posttranscriptional mechanisms of glucocorticoid antiproliferative effects. Hematol Oncol 2002; 20:17-32

51 Maliepaard M, van Gastelen MA, de Jong LA, Pluim D, van Waardenburg RC, Ruevekamp-Helmers $M C$, et al. Overexpression of the BCRP/MXR/ABCP gene in a topotecan-selected ovarian tumor cell line. Cancer Res 1999;59:4559-63

52 Robbiani DF, Finch RA, Jager D, Muller WA, Sartorelli AC, Randolph GJ. The leukotriene C(4) transporter MRP1 regulates CCL19 (MIP-3beta, ELC)dependent mobilization of dendritic cells to lymph nodes. Cell 2000;103:757-68

53 Bach MK, Brashler JR, Johnson MA. Inhibition by sulfasalazine of LTC synthetase and of rat liver glutathione S-transferases. Biochem Pharmacol 1985:34:2695-704.

54 Assaraf YG, Rothem L, Hooijberg JH, Stark M, Ifergan I, Kathmann GA, et al. Loss of multidrug resistance protein 1 (MRP1) expression and folate efflux activity results in a highly concentrative folate transport in human leukemia cells. J Biol Chem 2003:278:6680-6.

55 Baum CL, Selhub J, Rosenberg $\mathrm{IH}$. Antifolate actions of sulfasalazine on intact lymphocytes. J Lab Clin Med 1981;97:779-84.

56 ten Wolde S, Hermans J, Breedveld FC, Dijkmans BA. Effect of resumption of second line drugs in patients with rheumatoid arthritis that flared up after treatment discontinuation. Ann Rheum Dis 1997:56:235-9.

57 Jansen G, Scheper RJ, Dijkmans BAC. Chloroquine resistance in human CEM (T) cells is mediated by multidrug resistance protein 1. Ann Rheum Dis $2001 ; 60: 89$.

58 Dalton WS, Durie BG, Alberts DS, Gerlach JH, Cress AE. Characterization of a new drug-resistant human myeloma cell line that expresses P-glycoprotein. Cancer Res 1986;46:5125-30.

59 Legrand O, Perrot JY, Tang R, Simonin G, Gurbuxani S, Zittoun R, et al. Expression of the multidrug resistance-associated protein (MRP) mRNA and protein in normal peripheral blood and bone marrow haemopoietic cells. Br J Haematol 1996;94:23-33.

60 Laupeze B, Amiot L, Payen L, Drenou B, Grosset JM, Lehne G, et al. Multidrug resistance protein (MRP) activity in normal mature leukocytes and CD34positive hematopoietic cells from peripheral blood. Life Sci $2001 ; 68: 1323-31$ 
61 Zhou S, Schuetz JD, Bunting KD, Colapietro AM, Sampath J, Morris JJ, et al. The $A B C$ transporter $B c r p 1 / A B C G 2$ is expressed in a wide variety of stem cells and is a molecular determinant of the side-population phenotype. Nat Med 2001;7:1028-34.

62 Salmon SE, Dalton WS. Relevance of multidrug resistance to rheumatoid arthritis: development of a new therapeutic hypothesis. J Rheumatol Suppl 1996;44:97-101.

63 Maillefert JF, Maynadie M, Tebib JG, Aho S, Walker P, Chatard C, et al. Expression of the multidrug resistance glycoprotein 170 in the peripheral blood lymphocytes of rheumatoid arthritis patients. The percentage of lymphocytes expressing glycoprotein 170 is increased in patients treated with prednisolone. Br J Rheumatol 1996;35:430-5

64 Yudoh K, Matsuno H, Nakazawa F, Yonezawa T, Kimura T. Increased expression of multidrug resistance of P-glycoprotein on Th1 cells correlates with drug resistance in rheumatoid arthritis. Arthritis Rheum 1999:42:2014-15.

65 Llorente L, Richaud-Patin Y, Diaz-Borjon A, Alvarado DLB, Jakez-Ocampo J, De La FH, et al. Multidrug resistance-1 (MDR-1) in rheumatic autoimmune disorders. Part I: Increased P-glycoprotein activity in lymphocytes from rheumatoid arthritis patients might influence disease outcome. Joint Bone Spine 2000;67:30-9.

\section{Clinical Evidence - Call for contributors}

Clinical Evidence is a regularly updated evidence based journal available worldwide both as a paper version and on the internet. Clinical Evidence needs to recruit a number of new contributors. Contributors are health care professionals or epidemiologists with experience in evidence based medicine and the ability to write in a concise and structured way.

\section{Currently, we are interested in finding contributors with an interest in} the following clinical areas:

Altitude sickness; Autism; Basal cell carcinoma; Breast feeding; Carbon monoxide poisoning; Cervical cancer; Cystic fibrosis; Ectopic pregnancy; Grief/bereavement; Halitosis; Hodgkins disease; Infectious mononucleosis (glandular fever); Kidney stones; Malignant melanoma (metastatic); Mesothelioma; Myeloma; Ovarian cyst; Pancreatitis (acute); Pancreatitis (chronic); Polymyalgia rheumatica; Post-partum haemorrhage; Pulmonary embolism; Recurrent miscarriage; Repetitive strain injury; Scoliosis; Seasonal affective disorder; Squint; Systemic lupus erythematosus; Testicular cancer; Varicocele; Viral meningitis; Vitiligo However, we are always looking for others, so do not let this list discourage you.

\section{Being a contributor involves:}

- Appraising the results of literature searches (performed by our Information Specialists) to identify high quality evidence for inclusion in the journal.

- Writing to a highly structured template (about 2000-3000 words), using evidence from selected studies, within 6-8 weeks of receiving the literature search results.

- Working with Clinical Evidence Editors to ensure that the text meets rigorous epidemiological and style standards.

- Updating the text every eight months to incorporate new evidence.

- Expanding the topic to include new questions once every 12-18 months.

If you would like to become a contributor for Clinical Evidence or require more information about what this involves please send your contact details and a copy of your CV, clearly stating the clinical area you are interested in, to Claire Folkes (cfolkes@bmigroup.com).

\section{Call for peer reviewers}

Clinical Evidence also needs to recruit a number of new peer reviewers specifically with an interest in the clinical areas stated above, and also others related to general practice. Peer reviewers are health care professionals or epidemiologists with experience in evidence based medicine. As a peer reviewer you would be asked for your views on the clinical relevance, validity, and accessibility of specific topics within the journal, and their usefulness to the intended audience (international generalists and health care professionals, possibly with limited statistical knowledge). Topics are usually 2000-3000 words in length and we would ask you to review between 2-5 topics per year. The peer review process takes place throughout the year, and our turnaround time for each review is ideally 10-14 days.

If you are interested in becoming a peer reviewer for Clinical Evidence, please complete the peer review questionnaire at www.clinicalevidence.com or contact Claire Folkes(cfolkes@bmigroup.com). 